\title{
Clinical Reports
}

\section{Postoperative respiratory depression following excision of carotid body tumours}

Anis Baraka MB BCh DA DM PhD FRCA (Hon)
This report is of two adult patients who were scheduled for excision of carotid body tumours. One of the patients had bilateral tumours, while the second had a unilateral tumour. In the first, anaesthesia was maintained by nitrous oxide:oxygen and halothane $1-2 \%$. Postoperatively the intramuscular injection of meperidine $75 \mathrm{mg}$ resulted in apnoea, cyanosis, and lass of consciousness. In the second, anaesthesia was maintained by nitrous oxide:oxygen, supplemented by fentanyt $2 \mu \mathrm{g} \cdot \mathrm{kg}^{-1}$ and incremental doses of vecuronium. Following complete reversal of neuromuscular block, the patient became wide awake but spontaneous breathing was resumed at a rate of only two to three breaths per minute, and the oxygen saturation as monitored by pulse oximetry decreased $1050 \%$. Naloxone $0.4 \mathrm{mg}$ $\dot{N}$ increased the respiratory rate to 14 per minute and the oxygen saturation to $98 \%$. The report suggests that surgical excision of carotid body tumours, whether unilateral or bilateral, can be followed by severe postoperative respiratory depression. The complication may be attributed to opioid administration in the absence of peripheral chemoreceptor drive.

Deux adultes som programmés pour excision de tumeurs carotidiennes dont une est bilatérale, l'autre unilatérale. Le premier patient est anesthésié au protoxyde-oxygène avec halothane 1-2\%. A la période postopératoire, linjection intramusculaire de la mépéridine administrée au premier patient provoque de lapnée, de la cyanose et de linconscience. Pour le second patient, lanesthésie est entretenue avec du pro-

Key words

ANALGESICS: opioids:

RECEPTORS: chemoreceptors, carotid body; VENTILATION: anaesthetics, effect of, control.

From the Department of Anesthesiology, American University of Beirut, Beirut - Lebanon.

Address correspondence to: Dr. Anis Baraka, Professor and

Chairman, Department of Anesthesiology, American

University of Beirut, Beirut - Lebanon.

Accepted for publication 10th December, 1993. toxyde d'azoteloxygène avec supplémentation de fentanyl $2 \mu \mathrm{g} \mathrm{kg}^{-1}$ et des doses répétées de vécuronium. Après le renversement du bloc neuromusculaire, le patient se réveille, reprend une respiration spontanée à la fréquence de une ou deux à la minute. La saturation en oxygène mesurée par oxymétrie pulsée baisse à $50 \%$. Du naloxone, $0,4 \mathrm{mg}$ iv rétablit la fréquence respiratoire à 14 à la minute et la saturation à $98 \%$. Ces observations suggèrent que l'excision chirurgicale de tumeurs des corps carotidiens, quelle soit unilatérale ou bilatérale, peut être suivie de dépression respiratoire. On peut attributer cette complication à ladministration de morphinique en labsence de stimulation par les chémorecepteurs.

The carotid bodies are the peripheral chemoreceptors. ${ }^{1}$ Bilateral carotid body resection results in a decreased ventilatory response to hypoxia. ${ }^{2,3}$ A similar decreased hypoxic response has been observed following bilateral carotid endarterectomy ${ }^{4}$ or bilateral neck dissection. ${ }^{5}$ In contrast, hypoxic drive was not reduced in patients who had unilateral surgery.

Carotid body tumours are rare, usually unilateral, but are occasionally bilateral. ${ }^{6}$ Microscopically, there is a remarkable tendency to reproduce the architecture of the normal carotid body, ${ }^{7}$ suggesting that the tumours maintain the peripheral chemoreceptor function of the normal carotid bodies. The present report demonstrates that opioids may result in severe postoperative respiratory depression following surgical excision of bilateral carotid body tumours, or even a unilateral tumour.

\section{Case report \#1}

A 19-yr-old girl, $50 \mathrm{~kg}$, had bilateral firm non-tender masses, 3-4 cm in diameter on each side of the neck (Figure 1). The case was diagnosed as bilateral carotid body tumours. Carotid arteriography showed an ovoid mass located at the bifurcation of the common carotid artery and separating its two branches (Figure 2). The diagnosis was confirmed by biopsy which showed inter- 


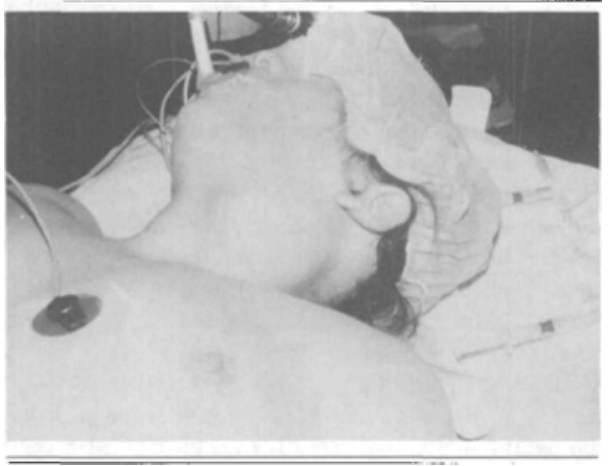

FIGURE 1 Photograph of the paticnt showing the carotid body tumour on the left side of neck.

communicating nests of polyhedral cells which had granular acidophilic cytoplasm and round or oval nuclei (Figure 3).

The patient was premedicated by meperidine $100 \mathrm{mg}$ and scopolamine $0.4 \mathrm{mg}$. Anaesthesia was induced with thiopentone $5 \mathrm{mg} \cdot \mathrm{kg}^{-1}$ and succinylcholine $2 \mathrm{mg} \cdot \mathrm{kg}^{-1}$. Following orotracheal intubation, anaesthesia was maintained with nitrous oxide:oxygen (3:1), supplemented with halothane $1-2 \%$. After excision of the carotid body tumours, anaesthesia was discontinued, the patient became conscious and the trachea was extubated.

One hour postoperatively, the patient complained of pain and meperidine $75 \mathrm{mg}$ was injected $\mathrm{im}$. Ten minutes later, the patient became unconscious, apnoeic, and deeply cyanosed, with a pulse rate of 40 per minute and systolic blood pressure of $70 \mathrm{mmHg}$. Controlled ventilation with $100 \%$ oxygen was followed by recovery of consciousness. However, spontaneous respiration could be maintained only by asking the patient to take a breath. Controlled ventilation was maintained for two hours, before the patient resumed normal spontaneous breathing.

\section{Case report $\# 2$}

This patient was a 30 -yr-old man, $80 \mathrm{~kg}$, who had right carotid body tumour diagnosed by histological examination. He was premedicated with meperidine $75 \mathrm{mg}$ and atropine $0.6 \mathrm{mg}$. Anaesthesia was induced with thiopentone $5 \mathrm{mg} \cdot \mathrm{kg}^{-1}$ and vecuronium $0.1 \mathrm{mg} \cdot \mathrm{kg}^{-1}$. Following tracheal intubation, anaesthesia was maintained with nitrous oxide:oxygen (2:1) supplemented by fentanyl 2 $\mu \mathrm{g} \cdot \mathrm{kg}^{-1}$ and incremental doses of vecuronium. After surgical excision of the tumour, anaesthesia was discontinued, and neuromuscular block was reversed by a mixture of atropine $0.02 \mathrm{mg} \cdot \mathrm{kg}^{-1}$ and neostigmine 0.05 $\mathrm{mg} \cdot \mathrm{kg}^{-1}$. The patient became wide awake. However,

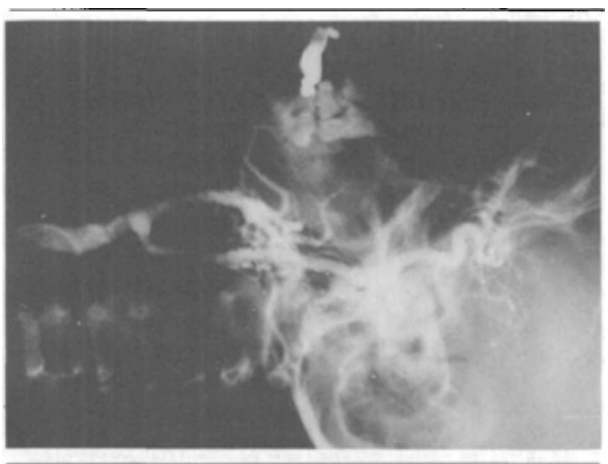

FIGURE 2 Carotid arteriography showing a $2 \times 3 \mathrm{~cm}$ ovoid mass located at the bifurcation of the common carotid artery, and separating its branches.

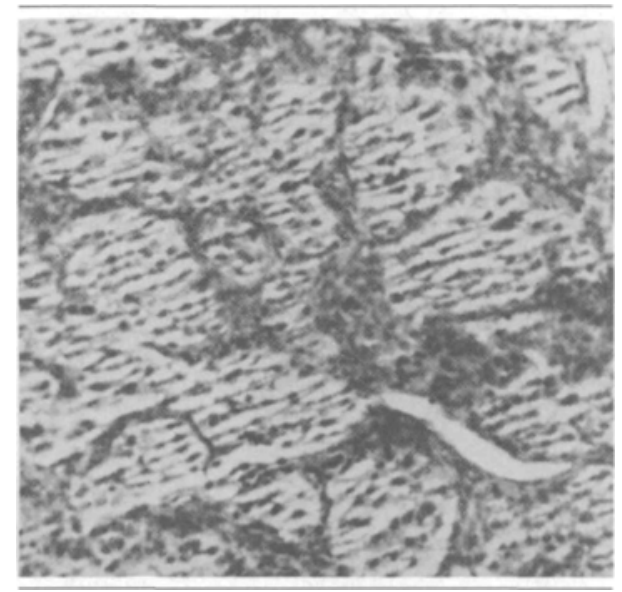

FIGURE 3 Section showing intercommunicating nests of polyhedral cells which have granulas acidophilic cytoplasm and round or oval nuclei in a stroma which is undergoing hyalinization in several fields.

spontaneous breathing was resumed at a rate of only two to three breaths per minute. Breathing room air, the oxygen saturation as monitored by pulse oximetry decreased to $50 \%$. Face mask oxygen increased the respiratory rate to six breaths per minute, and the oxygen saturation to $80 \%$. Naloxone $0.4 \mathrm{mg} i v$ increased the respiratory rate to 14 per minute, and the oxygen saturation to $98 \%$. Face mask oxygen was continued for one hour. Adequate spontaneous breathing and oxygen saturation were maintained when oxygen was discontinued. 


\section{Discussion}

The carotid bodies are the peripheral chemoreceptors which act as sensors for both hypoxia and hydrogen ion concentration. ${ }^{8}$ The responses are not simply additional, but exhibit a multiplicative effect. Usually the peripheral chemoreceptors are thought of as primarily hypoxia sensors, with secondary effects on the hypoxia response caused by hydrogen ion concentration. However, other investigators consider the peripheral chemoreceptors as primarily hydrogen ion sensors, with a secondary role for hypoxia in both enhancing the sensitivity to hydrogen ions and providing an independent weak response to hypoxia. Thus, the major function of the peripheral chemoreceptors is as an asphyxia sensor. 8

Bilateral excision of the normal carotid bodies can eliminate their peripheral chemoreceptor function, and hence decreased hypoxic response and hypoventilation will follow. ${ }^{2-5}$ Studies in patients undergoing carotid endarterectomy showed that unilateral endarterectomy had little effect on the hypoxic responses, whereas bilateral endarterectomy was followed by $13 \%$ depression of respiration and obtunded the hypoxic responses. In addition, hypoxia depressed ventilation instead of inducing hyperventilation, and shifted the carbon dioxide response curve to the right. ${ }^{4}$ In this situation, the central chemoreceptors 9 which respond selectively to carbon dioxide tension and hydrogen ion concentrations in the CSF and mixed venous cerebral blood will be the primary sensors that maintain regular breathing. Depression of the central chemoreceptor response by narcotics ${ }^{10}$ can therefore result in serious respiratory depression. Small doses of opioids have been reported to increase the intercept of the $\mathrm{PCO}_{2} /$ ventilation response curve on the $\mathrm{PCO}_{2}$ axis without change in the slope, but there is a marked change in slope at higher dosage. ${ }^{11}$

The carotid bodies as hypoxia sensors hypertrophy considerably as an adaptive response to chronic hypoxia in individuals living at high altitude. ${ }^{12,13}$ Also, the incidence of carotid body tumours is high among this population, suggesting that the hypertrophied carotid bodies and the carotid body tumours are active hypoxia sensors. Microscopically, carotid body tumours show a remarkable tendency to reproduce the architecture of the normal carotid body. ${ }^{7}$ Most of the reports refer to carotid body tumours as nonfunctional. ${ }^{6,7}$ However, this term refers to the nonchromaffinic nature of the tumour, and not to its chemoreceptor function.

Carotid body tumours are usually unilateral, but are occasionally bilateral. ${ }^{6,7}$ The present report showed that the administration of a normal dose of opioid can result in serious postoperative respiratory depression following excision of bilateral carotid body tumours. Respiratory depression was not observed when the same opioid was used for premedication. Severe postoperative respiratory depression also followed the surgical excision of a unilateral carotid body tumour. The carotid body tumour probably functions as a giant peripheral chemoreceptor which may suppress the chemoreceptor function of the second carotid body. Thus, administration of opioids to patients undergoing excision of bilateral carotid body tumours or even a unilateral tumour may result in serious postoperative respiratory depression. The resulting cerebral hypoxia will further depress rather than stimulate the CNS, with a consequent decrease of the central chemoreceptor response to carbon dioxide. ${ }^{14}$

The risk related to the lack of ventilatory defense against hypoxaemia is probably present in all patients during and immediately after potent inhalational anaesthetics which markedly attenuate the hypoxia drive at a concentration as low as $0.1 \mathrm{MAC}$, a level of anaesthesia which would continue for a considerable time during recovery. ${ }^{15-17}$

In conclusion, our report suggests that carotid body tumours maintain the peripheral chemoreceptor functions of the normal carotid bodies, as evidenced by their remarkable tendency to reproduce the architecture of the normal carotid bodies, and by the absence of respiratory depression following premedication by opioids before surgical excision of the tumours. However, the peripheral chemoreceptor function may be eliminated following excision of bilateral carotid body tumours or even a unilateral tumour, and hence opioids may result in serious postoperative respiratory depression. That is why the dose of opioids must be titrated in patients undergoing excision of carotid body tumours. Also, the patients must be observed carefully postoperatively, and a high inspired oxygen concentration should be administered during the recovery period.

\section{References}

1 Biscoe TJ. Carotid body: structure and function. Physiol Rev 1971; 51: 437-95.

2 Lugliani R, Whipp BJ, Seard C, Wasserman $K$. Effect of bilateral carotid body resection on ventilatory control at rest and during exercise in man. $\mathrm{N}$ Engl $\mathrm{J}$ Med 1971; 285: 1105-11.

3 Stulbarg MS, Winn WR. Bilateral carotid body nesection for the relief of dyspnea in severe chronic obstructive pulmonary disease. Physiological and clinical observations in three patients. Chest 1989; 95: 1123-8.

4 Wade JG, Larson CP Jr, Hickey RF, Ehrenfeld WK, Severinghaus $J W$. Effect of carotid endarterectomy on carotid chemoreceptor and baroreceptor function in man. $\mathrm{N}$ Engl $\mathrm{J}$ Med 1970; 282: 823-9.

5 Moorthy SS, Sullivan TY, Fallon JH, Dierdorf SF, Radpour $S$, DeAtley $R E$. Loss of hypoxic ventilatory response 
following bilateral neck dissection. Anesth Analg 1993; 76 : 791-4.

6 Bernard RP. Carotid body tumors. Am J Surg 1992; 163: 494-6.

7 Shamblin WR, ReMine WH, Sheps SG, Harrison EG Jr. Carotid body tumor (chemodectoma). Clinicopathologic analysis of ninety cases. Am J Surg 1971: 122: 732-9.

8 Duffin $J$. The chemoreflex control of breathing and its measurement. Can J Anaesth 1990; 37: 933-42.

9 Bruce EN, Cherniack NS. Central chemoreceptors. J Appl Physiol 1987; 62: 389-402.

10 Lee JK, Hanowell S, Kim YD, Macnamara TE. Morphine-induced respiratory depression following bilateral carotid endarterectomy. Anesth Analg 1981; 60: 64-5.

11 Nunn JF. Applied Respiratory Physiology. Cambridge: Butterworths 1987; 350-78.

12 Baraka $A$. Carotid body dysfunction. Middle East $\mathrm{J}$ Anesthesiol 1982; 6: 499-501.

13 Pacheco-Ojeda L, Durango E, Rodriguez C, Vivar N. Carotid body tumors at high altitudes; Quito, Ecuador, 1987. World J Surg 1988; 21; 856-60.

14 Phillipson EA, Bowes G, Townsend ER, Duffin J, Cooper $J D$. Carotid chemoreceptors in ventilatory responses to changes in verous $\mathrm{CO}_{2}$ load. J Appl Physiol 1981; 51: 1398-403.

15 Knill $R L$, Gelb $A W$. Ventilatory responses to hypoxia and hypercapnia during halothane sedation and anesthesia in man. Anesthesiology 1978; 49: 244-51,

16 Knill RL, Clement $J L$. Variable effects of anaesthetics on the ventilatory response to hypoxaemia in man. Can Anaesth Soc J 1982; 29: 93-9.

17 Knill $R L$, Clement $J L$. Site of selective action of halothane on the peripheral chemoreflex pathway in humans. Anesthesiology 1984; 61: 121-6. 